The intention of all this is to draw air into the top of the tube with a velocity of about $30 \mathrm{in}$. per sec., the air being removed progressively through the fine-mesh panels in the inner tube wall until finally a small residue of the volume originally induced actually reaches the surface of the mirror. This air is then withdrawn with radial symmetry across the face of the mirror through both the inner and the outer slots. All the fan speeds are adjustable at will over a wide range, and working trials will determine the best settings.

Experiments made at the Cambridge Observatories during the past year have shown that air-conditioning even of a comparativelysimple nature can give it great improvement in seeing conditions there; a remains to be seen how effective a carefully planned system can be when applied to a large telescope at a favourable observing site.

\title{
SCIENCE IN HUNGARY
}

\author{
By Prof. J. D. BERNAL, F.R.S. \\ Birkbeck College, London
}

GCIENCE teaching and research have been fully $D$ restored in Hungary. The damage caused in the fighting last autumn was, fortunately, on the whole slight. The only serious loss was the almost complete destruction of the natural history collections in the burnt-out National Museum [see following article]. The damage to the University was largely confined to the Geology Department. The material damage has been restcred; but there is a serious loss of books on stratigraphy and palæontology. In the University it is estimated that by lightening the courses and extending the term resumed in February, it will be possible to complete the work of the session.

The course of research work has been even less interrupted. The Academy and its institutes under the direction of Prof. Rusznyák are in full activity. In the Institute of Physics, the building for the nuclear research pile is nearing completion, and researches on nuclear physics, magnetism, spectroscopy and solid-state physics are being carried out. Prof. Jánossy is continuing his study of extended cosmic-ray showers and the phenomena of interference at low intensities.

There is much activity in the University research departments such as those of Prof. Erdey-Gruz and Dr. Lengyel in electrochemistry and the properties of concentrated ionic solutions. Prof. Straub is extending his work on enzyme synthesis by nucleic acid fractions, particularly for bacterial penicillinase, in conjunction with one of his students at present at the Medical Research Council laboratories at Mill Hill. In the Geology Department, Prof. Szadeczky-Kardoss is obtaining very interesting results in the high. pressure and temperature modifications of lignite and shales. At the Technical University, Prof. Gyulai, one of the first to study the properties of crystal 'whiskers', has discovered new related phenomena involving dislocations.
More significant, however, than the continuation of work in progress is the effort that is now being made to re-organize the whole scientific activity of the country to eliminate the errors and distortions of the past and to bring it into relation with a more realistic planning of industry and agriculture. In this replanning, scientists are playing a much more important part than formerly, for it is realized that the undertaking of the over-ambitious and misdirected industrial enterprises of the former regime could have been avoided if responsible scientific and technical advice had been taken in the first place. Scientists and engineers such as Dr. Gillemot, the rector of the Technical University, and Dr. Zentai and Dr. Valko, prominent in M.E.T.E.Sz., the organization of the scientists and technicians, are putting forward a scheme of central and specialized research and development councils on lines somewhat similar to those of the Department of Scientific and Industrial Research. They are also helping to draw up plans for Hungarian industry aimed at making fuller use of the special natural resources of the country, such as bauxite and uranium, and of its established industrial lines of production such as diesel engines, communication equipment and instruments. This would bring Hungary more in line with other small countries with specialized economies, such as Switzerland and Denmark, which would make it correspondingly more dependent on external trade and technical and scientific relations with other countries.

Hungarian scientists are anxious to renew and extend the contacts with British scientists broken off by the recent troubles. They would welcome an exchange of letters and reprints and also of individual visits which could now take place, thanks to the resumption of the tourist traffic.

\section{THE HUNGARIAN NATURAL HISTORY MUSEUM}

$\mathrm{T}$

HE collections of the Zoological Department of the Natural History Museum in Budapest, built up over the past hundred and fifty years, are well known; they represent the life-work of scientists such as János and Imre Frivaldszky, János Salamon Petenyi, Géza Fejérváry, Géza Horváth, Sándor Mocsáry, Erno Csiki, Kálmán Kertész, Gyula Madarász, to mention but a few. The collections contain not only the most complete Hungarian, that is, Carpathian fauna, but are also very rich in palæarctic and exotic material. Zoological material gathered by the collecting expeditions of Hungarian explorers have been deposited in the Museum; the names János Xántus, Lajos Biró, Kálmán (Katona) Kittenberger are well known in scientific circles. Xántus brought home a great deal of material 